\title{
Interaction Pattern of Moslem dan Christian Communities in Manado, Indonesia
}

\author{
Mardan Umar* \\ Department of Pancasila and Civic \\ Education \\ Faculty of Social Science, Manado \\ State University \\ Tondano, Indonesia \\ mardanumar@unima.ac.id
}

\author{
Theodorus Pangalila \\ Department of Pancasila and Civic \\ Education \\ Faculty of Social Science, Manado \\ State University \\ Tondano, Indonesia \\ theopangalila@unima.ac.id
}

\begin{abstract}
A prosperous, peaceful and harmonious life is everyone's dream. Religious differences are not a barrier to creating a harmonious social life. Likewise, between Muslims and Christians in Manado. This study examines the patterns of interaction between Muslims and Christians in Manado as a pattern that has been applied in heterogeneous life. This research uses a qualitative approach with descriptive methods. Data collected by observation, interview and documentation. The results showed two interaction processes namely associative and disassociative. Associative process can be seen in cooperation, tolerance and acculturation. While a dissociative process can be seen in competition and conflict. In addition, the existence of interfaith organizations has provided support for effective interaction and communication relations between religious communities. This results proves that the interactions in different religious communities can be realized in social life.

Keywords: peace, education, value, peaceful, local wisdom, heterogeneous.
\end{abstract}

\section{INTRODUCTION}

Harmonious relations between religious communities in heterogeneous societies is a social wealth that must be preserved and preserved. Muslims and Christians as fellow believers have the potential to mutually support one another, establish mutually beneficial and productive relationships in building society, nation and state. This is the wealth of Indonesia as a nation of different ethnicities, religions, races and groups but still one within the framework of the unitary state of the Republic of Indonesia.

Indonesia is a country with a very diverse background. By hence, opportunities for interethnic as well as interfaith conflicts often occur in various regions[1]. Indonesia is a mega diversity of cultures or countries with very large cultural differences, including religious differences[2]. An understanding of the importance of a harmonious life between religious communities is intended to minimize conflicts between religious believers as fellow citizens of Indonesia. Likewise, in the city of Manado, the community consisted of various religious adherents, namely Protestant Christians as the majority, followed by Islam, Catholicism, Hinduism, Buddhism and Confucianism[3].

This data shows that the people of Manado city have diversity in terms of religion. This diversity should be a pillar of national development [4]. In addition to religious diversity, Indonesia has wealth in terms of race ethnicity and cultural differences. In the context of plural society, interaction and communication become one of the important keys in maintaining togetherness and harmonizing life. Therefore, social interaction becomes very important to be used as a contemporary study.

Social interaction is a reciprocal relationship that influence each other between one individual with another individual. According to Walgito (2003: 57), "Social interaction is the relationship between the individual one with the other individual, the individual one can affect another individual or vice versa, so there is a mutual relationship" [5]. Likewise, Soekanto (2010: 55) defines social interaction, namely the reciprocal relationship between individuals and individuals, individuals and groups, and groups and groups. Soekanto further stated that social interaction is very useful in paying attention and studying various community problems such as forms of social interaction that take place between various ethnic groups or between educated groups and religious groups[6].

According to Soekanto, social interaction can take the form of associative social processes and disassociative social processes. These form of social interaction can be described as follows:

1. Associative Social Processes are social processes in the social reality of members of the community in a state of harmony and leading to patterns of cooperation. This social harmony creates an organized social condition or is called social older. this social harmony will result in social integration, which is a social pattern in which the members of the community are united and cooperating.

As for social processes that are associative can be divided into:

a. Cooperation (Cooperation). Cooperation is formed because they realize that they have the same interests so they agree to work together in achieving common goals. Based on the implementation there are four forms of cooperation, namely bargaining (bargaining), co-optation (co-optation), coalition (coalition), and joint-venture (joint venture).

b. Accommodation (Accomodation). Accommodation can be interpreted as a state, where there is a balance in the interaction between individuals or groups of people relating to social norms and values that apply in society.

The accommodation process can be divided into several forms: a) Coercion, is a form of accommodation where the process is carried out due to coercion. b) Compromise, is a form of accommodation in which the parties involved 
mutually reduce their demands, so that a resolution to the existing dispute is reached. c) Arbitration, is a way to achieve compromise if the parties facing are unable to achieve it themselves. d) Mediation, the existence of a neutral third party in the matter of existing disputes. The third party's task is to primarily seek a peaceful settlement. e) Conciliation, is an attempt to bring together the desires of the disputing parties for the achievement of a mutual agreement. f) Toleration, is a form of accommodation without formal approval. g) Stalemate, is an accommodation, where the parties who are in conflict because they have a balanced power stop at a certain point in carrying out the conflict. h) Adjudication, which is the settlement of a case or dispute in court.

c. Assimilation (Assimilation) is a social process in which the interacting parties identify themselves with group interests and goals.

d. Acculturation, is a social process that arises, when a group of human society with a certain culture is confronted with elements of a foreign culture in such a way that gradually the elements of the foreign culture are accepted and processed into their own culture, without causing loss of personality from the culture itself.

2. Dissociative Social Process, namely the state of social reality in disharmony as a result of conflict between members of the community.

a. Competition (competition) or competition is a struggle carried out by individuals or certain groups, in order to obtain a victory or competitive results, without causing threats or physical collisions on the side of their opponents.

b. Contravention, is a form of social process that is between competition and conflict or conflict.

c. Conflict, is a social process between individuals or certain community groups, due to differences in understanding and very basic interests, giving rise to a kind of gap or gap that blocks social interaction between the warring.

The heterogeneous condition in Indonesia requires maximum efforts in creating harmonious life. Therefore, efforts are needed to create a harmonious social life in diversity, respecting religious differences, still cooperating with each other in social affairs, creating a peaceful national and state life in a conducive climate[7]. In the condition of a pluralistic society, social integration efforts are needed. According to Pranawati, social integration is not just a unification of social differences but can be a means of evaluating relations between different communities[8]. This indicates that social interaction becomes an important part in the lives of heterogeneous Indonesian people, especially in Manado.

The basic framework of thinking in this study is heterogenity in society must be a strength and not cause conflict. In preliminary research, information was obtained that Muslim and Christian communities in Manado could live in harmony and peace in diversity. This is what raises the desire for researchers to examine How religious differences between people are able to keep them living in harmony and peace? And how the patterns of Muslim-Christian interaction in Manado to keep them living in harmony and peace?. The purpose of this study was to identify patterns of social interaction between Muslim and Christian communities in Manado.

\section{RESEARCH METHOD}

This research was designed using qualitative descriptive research. This research is more focused on the process, focusing on meaning and experience and interacting physically with people, locations, and institutions to observe or record behavior[9]. This research is located in the Kelurahan Islam, Tuminting sub-district, Manado City. Sources of data in this study are the community, community leaders, village government. This study places the researcher as the main instrument of sampling from the data source which was done purposively and snowball [10]. Data collection is done by observation, interview and documentation techniques and then analyzed by content analysis techniques, data reduction and presentation of conclusions.

\section{RESULTS AND DISCUSSION}

\section{A. Results}

Manado City residents are heterogeneous in terms of religion. The religions adopted are Protestant Christianity, Islam, Catholicism, Hinduism, Buddhism and Confucianism. Based on population census data in 2010, the number of residents is Christian 62.10 percent, Catholics 5.02 percent, while Muslims 31.30 percent and the rest are other religions.

According to the data of the Statistics Agency of the city of Manado, the Population Number by District in the City of Manado in 2017 can be described in the following table 2017.

TABLE I. POPULATION NUMBER By DisTRICT IN MANADO

\begin{tabular}{cccc}
\hline Kecamatan & \multicolumn{3}{c}{$\begin{array}{c}\text { Jumlah } \\
\text { Penduduk }\end{array}$} \\
\hline & Laki-Laki & Perempuan & Total \\
\hline Malalayang & 29432 & 28714 & 58146 \\
\hline Sario & 12243 & 12035 & 24277 \\
\hline Wanea & 28213 & 28667 & 56879 \\
\hline Wenang & 17750 & 18132 & 35882 \\
\hline Tikala & 14858 & 14746 & 29604 \\
\hline Paal Dua & 21197 & 21299 & 42496 \\
\hline Mapanget & 26948 & 27116 & 54063 \\
\hline Singkil & 24871 & 23446 & 48317 \\
\hline Tuminting & 26323 & 26369 & 52692 \\
\hline Bunaken & 10829 & 10846 & 21675 \\
\hline Bunaken & 3169 & 2933 & 6102 \\
Kepulauan & \multicolumn{2}{|c|}{ Source: BPS-Statistic of Manado 2017 }
\end{tabular}

Even so heterogeneous, but the people of Manado really appreciate the attitude of life tolerant, harmonious, open and dynamic. Therefore, the city of Manado has a relatively conducive social environment and is known as one of the relatively safe cities in Indonesia. When Indonesia was vulnerable, it was caused by political shocks around 1999 and various riots in the cities in Indonesia. The city of Manado can be said to be relatively safe. This is reflected in the motto of the people of Manado namely Torang samua basudara which means "We are all brothers".

This motto becomes the strength of brotherhood among religious people in social life. When faced with problems that disrupt peace and harmony, always prioritize brotherhood values, baku baku sayang (love each other), baku baku bae 
(do good deeds), baku baku jaga (guarding each other), because Torang Samua Basudara (we are all brothers), We are all God's creations.

This was stated by Lutvia Alwi Malabar, the community interviewed in this study. She explained that the social interaction of Muslim and Christian communities was manifested in mutual respect and respect for one another. Silaturrahmi (social relationship) between people with different religions is still maintained. Every time there is a social activity or a family celebration to support one another by respecting each other's religious values. This is implemented by providing assistance with the spirit of mutual cooperation.

Explanation from the government delivered by Hery Anwar, Head of the Islamic village, He stated that the majority of Islam urban villages are Muslim. Many migrants invest in buying land, buildings and even living in areas that are predominantly Muslim. Because they feel a comfortable atmosphere. Muslim and Christian communities in this region mostly have very strong tolerance values. Religion is not a problem for neighbors because of mutual respect and never enlarges discussions about differences.

In religious worship activities such as Eid al-Fitr Prayer, guarded by members of the community who are Christians. on the contrary in the Christmas Service, security is guarded by Muslim youth. This fact is the uniqueness of religious people in the city of Manado, they care for one another and love one another.

Several communities interviewed also stated the same thing related to the social interaction of Muslim and Christian communities in the Islam village. For them, harmonious social relations and a sense of brotherhood have been built up in the city of Manado. Although there is potential for conflict, all of that can be resolved with good dialogue and communication.

This fact shows that Muslim and Christian societies have implemented inseparable relationships due to religious differences. For this society, religion teaches brotherhood, cooperation, please help and respect one another. As Wantu's research, social interaction is assessed from four indicators, namely: Making a feedback relationship in interaction; Mutual influence in interactions; Has clear goals and intentions within interaction; and Using social media in interactions[11].

The results of field observations in the Kelurahan Islam in Manado show a harmonious relationship between people of different faiths. The religious and educational center is firmly established and is operating safely and smoothly. Among them with the Awwal Fathul Mubien Mosque which was renovated with the help of government and nongovernmental organizations.

Interestingly from the field observations, there is a church that reads Yarden Singkil Kampung Islam Church. The location is administratively already recorded in other villages, but it is very close to the community of Kampung Islam and still includes the name of the Islamic village on the church's signboard. This is unique in the village of Islam that stands a magnificent church and its followers can live safely and peacefully.

\section{B. Discussion}

Based on research results that show positive social interactions between Muslim and Christian communities, it can be said that interaction pattern illustrates the existence of an associative process that is so thick in the religious community in the city of Manado. This relationship is built continuously starting from small to large scope. Cooperation, tolerance and acculturation become the dominant process in the pattern of social interaction. However, as the provincial capital with various advances and rapid information and education levels, a dissociative process has also emerged in Muslim and Christian communities in Manado.

Competition as a consequence of competition in obtaining personal, group and group comfort is also apparent in society. Conflicts have arisen with religious issues, related to the construction of places of worship in some cases, but were quickly suppressed by the government and local religious leaders. In addition, political factors in the contestation of both the legislative and regional head elections, often also put religious adherents in a face to face position. However, this phenomenon can be categorized as low because the majority of the people of Manado are objectively minded with the conditions and the national and regional political situation.

Strengthening local community values is also a power in creating a safe and peaceful life in Manado. The values of life that have been embedded in daily life interactions, including Life Philosophy inherited Sam Ratulangi Sitou Timou Tumou Tou which means humans live to humanize other humans. In this way, a society that is tolerant, mutual assistance, mutual respect and respect, supports in kindness and helps and cares for others is realized. All residents of the city of Manado from various religious backgrounds have upheld that philosophy and become a stronghold for the threat of community disintegration. In relation to the philosophy of local values, Umar mentioned that Communities have an important role in preserving the nature and local culture of the community. The existence of the community is one of the important elements in the existence of local wisdom values[12].

So that, efforts to realize good social relations can be done by instilling a love for others, accept differences, respect others, fair, obey the rules, tolerant, cooperation, and avoiding conflict. A life of mutual care, mutual affection, mutual remembrance, becomes a strength in the social interaction of the people of Manado, both Muslim and Christian. The reality of people who live in harmony between religious communities in Manado, is progressing from time to time. Swazey as cited by Suleman, saw that the relationship of adherents of both Christianity and Islam had shaped the identity of a harmonious and tolerant society[13].

Another strength possessed by the people of Manado in terms of inter-religious relations, especially Muslims and Christians, is the formation of a number of interfaith organizations which become a forum for communication and friendship among religious leaders in discussing various matters concerning diverse interfaith relations. For example the existence of FKUB or Forum for Religious Harmony and the organization BKSAUA (Interfaith Cooperation Agency) and BAMAG (Interfaith Deliberation Council) which is tasked with working together to build two-way communication between religious leaders and the people. 
In social interaction, it is not always free from conflict. However, the ability of the community to respond to conflict is very important. in this situation, the role of philosophical values of life and religious values becomes a force for social relations.

\section{CONCLUSION}

The pattern of social interaction in realizing harmony of life between religious communities can be seen in two patterns of interaction. In the Muslim and Christian communities in Manado an associative social process (cooperation, tolerance and acculturation) and a dissociative process can be seen in competition and conflict.

In addition, the existence of interfaith organizations has provided support for effective interaction and communication relations between religious communities. Likewise the Government's role as the holder of power for the community and its citizens gives attention to the preservation of the religious and social values of the community.

\section{ACKNOWLEDGMENT}

We thank to Head of Islam Village Government, public figure and also all the informant in Islam Village as a research location. We would also like to show our gratitude to the community of Islam village to share their experiences with us during the course of this research, and we thank to reviewers for their so-called insights.

\section{REFERENCES}

[1] S. Mokodenseho and I. S. Wekke, "TOLERANSI BERAGAMA DAN PEMBELAJARAN AGAMA ISLAM: HARMONI MASYARAKAT MINORITAS MUSLIM MANADO," in Prosiding Seminar Nasional \& Temu Ilmiah Jaringan Peneliti, pp. 67-75.
[2] M. M. Iqbal, "Pendidikan Multikultural Interreligius: Upaya Menyemai Perdamaian dalam Heterogenitas Agama Perspektif Indonesia," Sosio Didakt., vol. 1, no. 1, pp. 89-98, 2014.

[3] Rahman Mantu, "MEMAKNAI 'TORANG SAMUA BASUDARA' (MANAJEMEN DAKWAH BERBASIS KEARIFAN LOKAL DI KOTA MANADO)," J. IAIN Manad., pp. 42-65, 2018.

[4] M. Umar, "Pembinaan Kedamaian Hidup Beragama melalui Optimalisasi Pendidikan Agama," Iqra', vol. 10, no. 1, pp. 1-38, 2018.

[5] B. Walgito, Psikologi Sosial. Yogyakarta: Andi Offset, 2003.

[6] S. Soekanto, SOSIOLOGI SUATU PENGANTAR. Jakarta: Rajawali Press, 2010.

[7] M. Umar, T. Pangalila, and J. Biringan, "Peace Education : An Effort to Realize a Peaceful Social Life in Indonesia," in Advances in Social Science, Education and Humanities Research, 2nd International Conference on Social Science (ICSS 2019), 2019, vol. 383, no. Icss, pp. 682-685.

[8] R. Pranawati, "Metode Membangun Masyarakat Agama yang Toleran untuk Integrasi Sosial," in Modul Kebebasan Beragama dan Integrasi Sosial di Indonesia, no. March 2011, 2011, pp. 125-156.

[9] J. W. Creswell, Research Design Qualitative Quantitative and Mixed Methods Approaches, 4th ed. California: SAGE, 2014.

[10] Sugiyono, Download Metode Penelitian Kuantitatif Kualitatif dan $R$ $\& D$. Bandung: Alfabeta, 2017

[11] T. Wantu, "STUDENTS' SOCIAL INTERACTION ABILITY AT CLASS VIII OF," in Advances in Social Science, Education and Humanities Research. 9th International Conference for Science Educators and Teachers (ICSET), 2017, vol. 118, pp. 1093-1099.

[12] A. Supriati and M. Umar, "The Role of Coastal Communities to Preserve Local Wisdom ( A Study in Community of Bunaken Island, Indonesia )," in Advances in Social Science, Education and Humanities Research. 2nd Annual Civic Education Conference (ACEC 2019), 2020, vol. 418, no. Acec 2019, pp. 26-29.

[13] F. Suleman, "Keberagaman Budaya dan Agama di Kota Manado," Endogami, pp. 55-62, 2007. 